\title{
A Comparison of Performance Measures for Finding the Best Measure of Business Entity Performance:
}

\section{Source from the Tehran Stock Exchange}

\author{
Hamidreza Javadian Kootanaee ${ }^{1}$, Akbar Javadian Kootanaee ${ }^{2} *$, Hamid \\ Foladi Talari ${ }^{3}$ and K. Nagendra Babu ${ }^{4}$
}

\begin{abstract}
One of the most important goals of a business unit is creating value and wealth for its shareholders and attracting them for more investment. The success of management, and consequently the success of the business unit, is measured by the level of value created for its shareholders. Economic Value Added is a
\end{abstract}

${ }^{1}$ Faculty of Accounting, Islamic Azad University of Firoozkuh.

e-mail: Hamidreza.Javadian@yahoo.com

${ }^{2} \mathrm{Ph} . \mathrm{D}$. student, University of Mysore and lecturer in Department of Accounting, Islamic Azad University. e-mail: Akbar.javadiankootanaee@yahoo.com 3Expert in Accounting and Finance. e-mail: Hamid_foladi@yahoo.com 4Associate Professor of the Department of Studies in Commerce, University of Mysore. e-mail: nagendrababu280@yahoo.com

* Corresponding author

Article Info: Received : September 3, 2012. Revised : October 9, 2012.

Published online : December 12, 2012 
performance measure that is in essence related to the market value of a firm. This measure focuses on the ability of business organizations to create return beyond cost of shareholders equity based on certain risk.

In this research, the interrelationship between EVA, Cash Flows, and Earning per Share is examined to find the best measure of business organizations performance. The reason for choosing traditional measures as Earning per Share and cash flow generated by operations is the high concern for profit making and liquidity in firms.

The time period is between 2005 and 2009, and studied firms are listed companies on the Tehran Stock Exchange. In addition, a linear regression model is used for panel data, and analysis is done using Eviews. The results of the research show that EVA comparison to OCF and EPS is a more efficient measure than MV.

JEL classification numbers: G17, G32, M41, M21, L21, L25

Keywords: Economic Value Added (EVA), Net Operating Profit after Tax (NOPAT), Operating Cash Flow (OCF).Weighted Average Cost of Capital (WACC)

\section{Introduction}

Value creation for shareholders has become a concern of management, and has become one of the most important goals of business organizations. Management considers whether and which variables help in value creation. The main question is determining the best measure for assessing the performance of economic institutions to help investors find appropriate investment opportunities and to help managers create value for the firm. So far there have been developed various performance evaluation measures, among them Economic Value Added (EVA) is one of the last. Using EVA, the economic profit of a firm can be measured, reducing criticism against accounting profit. As EVA considers all costs of capital, it eliminates the problem of considering only debt costs and therefore showing higher profits than otherwise.

EVA takes into account the opportunity cost of all resources, showing optimum resource allocation, value creation and shareholder wealth. Once resources are allocated efficiently, the opportunity cost of resources is eliminated and shareholder value is created, resulting in profit and a return on investment.

\section{Literature Review}

\subsection{Economic Value Added}

For many years economists believed that a business organization must earn more 
than its cost of equity in order to keep and develop its operations. In the 20th century this concept obtained an operational status and came to be called Residual Income. General Motors applied this concept in the 1920s. In 1965 Solomon's proposed RI as an internal measure of performance evaluation for business organizations, and in $(1973,1982), \mathrm{R}$. Anthony proposed it as an external measure of performance evaluation (Biddle et all,1999).

One type of residual income calculation is called Economic Value Added. EVA was developed by the consultation firm of Stewart \& Co., and is a registered trademark of that firm. The calculation of EVA includes a deduction for the cost of capital, and also adjusts accounting income to more accuracy reflect the economic effect of transactions and the economic values of assets and liabilities. In general, these adjustments move the income calculation further from the reliability end of the relevance versusre liability continuum, and closer to the relevance-end of that continuum. Since the 1990s, EVA has helped revive the popularity of residual income. However, it should be emphasized that obtained trademark potential on the term "EVA, "the concept of residual income precedes EVA by almost half a century, and it is in the public domain(Caplan,2009).

In a 1994 research address published in the Harvard Business Review, Stern Stewart stressed that "EVA" is the best wealth making measure and it outperforms accounting based measures in determining shareholders wealth."The same year, the Jenkins Committee of the AICPA proposed that, to improve financial reporting, those companies that use EVA as their internal performance evaluation, should use it as their external measure as well (Biddle, 1997).

EVA is defined as net operating profit after tax (NOPAT), which is reduced by cost of capital. Cost of Capital includes all financing expenses which are included in the Weighted Average Cost of Capital (WACC).

The formulation of EVA is as below:

$$
E V A=N O P A T_{t}-W_{A C C}\left(\text { Capital }_{t-1}\right)
$$

- $\quad$ NOPAT is the net operating profit after tax at the end of period $t$

- WACC is the weighted average cost of capital

- Capital is the book value of total capital at the end of period t-1

As inferred from the formula, value drivers in EVA are classified into NOPAT, WACC and Capital. (Stewart, 1991) There are two operating and financial perspectives with which to compute Capital and NOPAT results in the same end. Below, each approach is summarized.

Based on operating perspective, Capital and NOPAT are computed as follow:

Based on financial perspective, NOPAT and Capital are computed in three step in which

First step is elimination of liability effect. In this step all debt, present value of debt, and interest charges of liabilities, including interest on loans, are added back to accounting profit.

Next step is elimination of other financial deviation effects. To improve interest, elimination of financial deviation effects is critical. In this step, capital provided 
by preferred shareholders and minority interest is added back to capital, and profit allocated to these suppliers is added back to NOPAT.

Table 1: Calculation of Capital and NOPAT (Operating Viewpoint)

\begin{tabular}{llll}
\hline Capital & & NOPAT & \\
\hline Net working capital (NWC) & $\mathrm{XX}$ & Net sales & $(\mathrm{XX})$ \\
Net fixed asset (NFA) & $\mathrm{XX}$ & CGS & $(\mathrm{XX})$ \\
Other assets & $\mathrm{XX}$ & Operating costs & $\mathrm{XX}$ \\
Other capital equivalents & $\mathrm{XX}$ & Operating profit & $\mathrm{XX}$ \\
CAPITAL & $\mathrm{XX}$ & Other incomes (costs) & $\mathrm{XX}$ \\
& & Increase in shareholders equity & $(\mathrm{XX})$ \\
& & Tax & $\mathrm{XX}$ \\
\hline
\end{tabular}

NWC = Current asset - (Current liability - interest bearing liabilities)

Interest bearing liabilities $=$ Short term facilities from banks - sales receivable)

NFA = book value of Fixed income - Accumulated depression (AD)

Last step is elimination of accounting deviations. Account deviations are removed by adding back the equity equivalent to capital and periodical changes to NOPAT. Referring to the above mentioned steps, the calculation of cost of equity capital, based on financial perspective, is summarized as follow:

Table 2: Calculation of Capital and NOPAT (Financing Viewpoint)

\begin{tabular}{ll|lc}
\hline \multicolumn{1}{c|}{ Capital } & \multicolumn{2}{c}{ NOPAT } & $\mathrm{XX}$ \\
\hline Common equity & $\mathrm{XX}$ & Net profit & $\mathrm{XX}$ \\
Preferred equity & $\mathrm{XX}$ & Preferred dividend & $(\mathrm{XX})$ \\
Minority interest & $\mathrm{XX}$ & Minority interest provision & $\mathrm{XX}$ \\
Interest bearing liabilities & $\mathrm{XX}$ & Interest expense after tax & $\mathrm{XX}$ \\
Equity equivalent & $\underline{\mathrm{XX}}$ & Increase in equity equivalent & $\mathrm{XX}$ \\
CAPITAL & $\mathrm{XX}$ & NOPAT & \\
\hline
\end{tabular}

\subsection{Cost of Capital}

Each firm has its own risks and rates of return. Each group of investors, like holders of bonds, and preferred and common stock, seek a return proportional to risk taken. Cost of capital is the lowest rate of return a firm must obtain in order to secure its investors' return (Neveu, 1986).

Cost of capital is significant from various aspects, including its applicability in making optimal capital structure decisions, and its use in debt and performance measures and in discounting future cash flows in valuation. Furthermore, ignorance of the cost of equity capital in calculation of net profit justifies the necessity of focusing on this subject.

Cost of capital includes components of capital that construct the sum of the capital structure. The main components of capital structure are debit, preferred stock, common stock and retain earnings. Since each holder of the mentioned financial resources has its own expectation for rate of return, the cost of acquiring each item 
is different. Further, due to their varied nature, the calculation method for their cost of capital is varied.In order to determine a firm's cost of capital, it is necessary to calculate the cost of every component of capital separately and based on their proportion in capital structure. : (Neveu, 1986). Thus the average cost of capital is computed as follows:

$\mathrm{WACC}=\left(\frac{D}{D+E}\right) K_{d}+\left(\frac{E}{D+E}\right) K_{e}$

where:

$\mathrm{D}$ is the total debt

$\mathrm{E}$ is the total shareholder's equity

$\mathrm{Ke}$ is the cost of equity

$\mathrm{Kd}$ is the cost of debt

Cash Flow Statement

Cash flow statements indicate cash inflows and cash outflows during a given time period. When used with other financial statements, this information helps investors, creditors and others to determine the credit rating of a firm. For example, cash resulting from the issuing of bonds shows whether a firm is not only liable to pay its interest rate, but also whether it must pay the deposit at particular due date. Therefore, the cash flow statement is useful in analyzing the past and future rate of return of a firm, and its ability to pay back its debts (Warren. et al. 2004)

\section{Data and Methodology}

In general, information sources, including information related to Tehran Stock Exchange, consists of annual financial statements and accompanying notes present in TSE. Furthermore, required statistical information of companies is collected and analyzed using the "TADBIR PARDAZ" software and stock exchange data base.

Research Design To be included in the sample, the firm had to satisfy the following criteria:

1. The firm must be listed on the Tehran Stock Exchange before 2005

2. The firm's initial data must have been submitted to the Tehran Stock Exchange for 5 continues years

3. The firms in certain industries are systematically excluded because of the component data requirements (i.e. banks and insurance companies)

In this research, the total number of listed companies by the end of the year 2009 are 346 companies from 37 various industries. After the above adjustments, among these 346 companies, 117 remained, and with respect to the sample volume described below, a categorized random sampling method is used. 


\section{Research Model}

In this research, the goal is to forecast changes in the dependent variable (market value) based on the independent variables- EVA, EPS, operating cash flow (OCF) and a simple linear regression is applied, the general equation is as below:

$$
\mathrm{Y}=\beta_{0}+\beta_{1} X_{1}+\varepsilon
$$

In order to answer the questions, a linear regression model for panel data is used, and data are analyzed using EViews 6 . The regression formula applied for panel data is presented below:

$$
\mathrm{MV}_{\mathrm{it}}=\alpha_{\mathrm{i}}+\beta_{1} \mathrm{EVA}_{\mathrm{it}}+\beta_{2} \mathrm{CFO}_{\mathrm{it}}+\beta_{3} \mathrm{EPS}_{\mathrm{it}}+\varepsilon_{\mathrm{it}}
$$

$\mathrm{i}=1,2, \ldots, \mathrm{N}$

$\mathrm{N}=$ number of cross sections in panel data which in this research equals to number of companies that are analyzed.

$\mathrm{t}=1,2, \ldots, \mathrm{T}$

$\mathrm{T}=$ time period

The equation accomplished is as follows:

$\mathrm{MV}(\mathrm{X})=\mathrm{C}(\mathrm{X})+$ PER_EFFECT $+\mathrm{C}(1)+\mathrm{C}(2) * \mathrm{CFO}+\mathrm{C}(3) *$ EVA $+\mathrm{C}(4) *$ EPS The output of the company=latitude from company reference + latitude from a temporal reference +latitude from a common reference + coefficient of a common angle in any variable for all companies.

In the next step, for the purpose of the $\mathrm{F}$ test and the $\mathrm{t}$ test, there is a need to test for the independence of the error hypothesis for which we use the Durbin-Watson test.

Research Hypothesis Theoretical principles and recent researches lead to the following hypothesis (stated in alternative form):

1) The EVA effect is greater than that of OCF on the market value of listed companies on the Tehran Stock Exchange.

2) The EVA effect is greater than that of EPS on the market value of listed companies on the Tehran Stock Exchange.

\section{Empirical Result}

This study primarily presupposes both cross-section and time series effects as fixed, then calculates the rates of changes based on companies, time and common interests, and decides through a Flasher test whether the equation is significant. Thereafter, this study begins to identify the level of amplitude error of each of the variables to find if it has any effectiveness or significance.

This study again presupposes both cross-section and time series randomly, and 
continues to exercise the studies as mentioned above.To ensure that the above said effects are correct, we pose both cross-section and time series as random, and use the Hausman test .Based on the Hausman test, the first method, that of a fixed presupposed cross-section and time series, is correct because the figure for Prob0, or significance of variables in the Hausman test, is larger than 0.05.

\section{Table3: Sums of The Hausman Test}

\begin{tabular}{|c|c|c|c|}
\hline $\begin{array}{l}\text { Correlated random effects - Haus } \\
\text { Pool :Test } \\
\text { Test cross-section and period ran }\end{array}$ & dom effects & & \\
\hline Test summary & Chi-sq .statistic & Chi-sq.d.f & Prob. \\
\hline Cross-section random & 0.000000 & 3 & 1.000 \\
\hline Period random & 0.000000 & 3 & 1.000 \\
\hline Cross-section and period random & 0.000000 & 3 & 1.000 \\
\hline
\end{tabular}

\section{Test of Hypothesis 1}

Null hypothesis $\left(\mathrm{H}_{0}\right)$ : EVA and CFO don't have meaningful effect on market value of listed companies on Tehran stock exchange.

\section{$\mathrm{H}_{0}: \boldsymbol{\rho}=\mathbf{0}$}

Alternative hypothesis $\left(\mathrm{H}_{1}\right)$ : EVA and CFO have meaningful effect on market value of listed companies on Tehran stock exchange.

\section{$\mathrm{H}_{1}: \rho \neq 0$}

Table 4: statistical results from the test of hypothesis 1 (Period and Cross-section are Fix)

\begin{tabular}{clllllll}
\hline \multirow{2}{*}{ Period } & $\begin{array}{l}\text { Cross- } \\
\text { section }\end{array}$ & $\begin{array}{l}\text { Coefficient } \\
\text { EVA }\end{array}$ & OCF & EVA & OCF & Prob)F-statistic( & R-squared \\
& Fix & -0.00509 & $5.05 \mathrm{E}-05$ & 0.0414 & 0.9473 & 0.00000 & 0.54337 \\
\hline
\end{tabular}

Table 5: statistical results from the test of hypothesis 1 (Period and Cross-section are Random)

\begin{tabular}{lllcllll}
\hline \multirow{2}{*}{ Period } & $\begin{array}{l}\text { Cross- } \\
\text { section }\end{array}$ & $\begin{array}{l}\text { Coefficient } \\
\text { EVA }\end{array}$ & OCF & EVA & OCF & $\begin{array}{l}\text { Prob)F- } \\
\text { statistic( }\end{array}$ & R-squared \\
Random & & -0.000122 & 0.000162 & 0.9488 & 0.7468 & 0.058659 & 0.020702 \\
\hline
\end{tabular}

As already established, relying on the Hausman test, the second test is not valid and thus we shall start to analyze the results as obtained in Table 4 in order to deal with the fixed theory of cross-section and time series .Considering the figure for the test error level, the test error of the Fisher test is significant as its figure is a 0.05 digit .Thus, we can proceed to analyze next steps of test .In continuation, as already mentioned, the variable EVA on MV has a significant impression, as the significant figure of this variable is equal to 0.0414 , which is smaller than the 
established meaningful level of 0.05 .Therefore, it can be said that EVA, in its connection with $\mathrm{MV}$, is a more effective and efficient measure than (OCF).

\section{Test of Hypothesis 2}

Null hypothesis $\left(\mathrm{H}_{0}\right)$ : EVA and EPS don't have meaningful effect on market value of listed companies on Tehran stock exchange.

\section{$\mathrm{H}_{\mathbf{0}}: \boldsymbol{\rho}=\mathbf{0}$}

Alternative hypothesis $\left(\mathrm{H}_{1}\right)$ : EVA and EPS have meaningful effect on market value of listed companies on Tehran stock exchange.

\section{$\mathrm{H}_{1}: \rho \neq 0$}

Table 6: statistical results from the test of hypothesis 2 (Period and Cross-section are Fixed)

\begin{tabular}{|c|c|c|c|c|c|c|c|}
\hline \multirow{2}{*}{ Period } & \multirow{2}{*}{$\begin{array}{l}\text { Cross- } \\
\text { section }\end{array}$} & \multicolumn{2}{|c|}{ Coefficient } & \multicolumn{2}{|c|}{ Prob. } & \multirow{2}{*}{ Prob(F-statistic) } & \multirow{2}{*}{ R-squared } \\
\hline & & EVA & EPS & EVA & EPS & & \\
\hline \multicolumn{2}{|c|}{ Fix } & -0.00509 & -0.12833 & 0.0414 & 0.0234 & 0.00000 & 0.543379 \\
\hline
\end{tabular}

Table 7: statistical results from the test of hypothesis 2 (Period and Cross-section are Random)

\begin{tabular}{|c|c|c|c|c|c|c|c|}
\hline \multirow{2}{*}{ Period } & \multirow{2}{*}{$\begin{array}{l}\text { Cross- } \\
\text { section }\end{array}$} & \multicolumn{2}{|c|}{ Coefficient } & \multicolumn{2}{|c|}{ Prob. } & \multirow{2}{*}{$\begin{array}{l}\text { Prob)F- } \\
\text { statistic( }\end{array}$} & \multirow{2}{*}{ R-squared } \\
\hline & & EVA & EPS & EVA & EPS & & \\
\hline \multicolumn{2}{|c|}{ Random } & -0.000122 & -0.01549 & 0.9488 & 0.0068 & 0.058659 & 0.020702 \\
\hline
\end{tabular}

Again, as established by the Hausman test, the second test is invalid and thus allows us to deal with the analysis of results as obtained in Table 6 .The test is significant as noted in the figure representing the level of Fisher's test error, because its value is less than 0.05 and thus we can analyze the next steps of test. It is, therefore, noted that both variables EVA and EPS have significant effects on $\mathrm{MV}$, because the significant values in both variables are less than the significant level of 0.05 .It is, however, to be said that EVA has a significant value of 0.0414, which approaches the significant level of 0.05 and indicates that EVA affects MV more than EPS.

In addition, the adjusted $\mathrm{R}$ square is equal to 0.543 , which shows that 54.3 percent of MV are explained by EVA and EPS .

\section{Conclusion}

Each business unit must evaluate weaknesses of previous actions for its operation's continuity and to enable it to choose the right procedures and desired policies. In this regard, strategic management also is in need of planning and resource allocation to find the optimum breakeven point among its resources in existing opportunities. In this research, the interrelationship between EVA, cash 
flows, and earning per share is studied to find the best measure of business organizations performance. It is concluded that both variables EVA and EPS have significant effects on MV. Furthermore, the result shows that EVA, in connection with MV, stands as a more efficient index than EPS.

\section{References}

[1] Biddle, G; R, Bowen \& J, Wallace, 1999, "Evidence on EVA", Journal of applied Corporate Finance, Vol. 12, No 2

[2] Biddle, G; R, Bowen \& J, Wallace, 1997, "Does EVA Beat Earning? Evidence on Association with Stock Returns and Firm Values", Journal of Accounting and Economics, Vol. 24, No 3

[3] Caplan, Dennis, (2006), Management Accounting Concepts and Techniques, Textbook, chap. 22

[4] Neveu, Raymond P., Fundamentals of Managerial Finance, 3rd Ed., Cincinnati, Ohio: South - Western Publishing Co. 1989

[5] Stewart, G., Bennett" The Quest for Value: A Guide for Senior Mangers" Harper Collins publisher Inc 1991

[6] Warren, Carl S., James M. Reeve, and Philip E. Fess. 2004. Financial Accounting (9th ed.), South- Western College Publishers, Mason, Ohio. 